\title{
Detection of aflatoxins in smoked fish (Clarias anguillaris) sold in the Bamako District
}

\begin{abstract}
Summary
Fishing is a millennial tradition in Mali. It is an important sub-sector of the Malian economy, depending in particular on the Niger River, which is 4,200 km long, including 1,700 km in Mali. Its potential importance of existing resources is expressed in its socio-cultural role, job creation, food security and poverty reduction. Due to their pervasiveness, mycotoxinproducing molds are able to reduce the nutritional value of smoked fish by developing several mycotoxins. Smoked fish contaminated with mycotoxins have harmful effects on human health. Samples of smoked fish for sale were collected in the six communes of the district of Bamako and analyzed to determine the fungal flora as well as the concentration of mycotoxins. The mycoflora study of smoked fish has shown that the concentration of fungi varies between $0.5 .10^{4} \mathrm{CFU} / \mathrm{g}$ to $14.10^{4} \mathrm{CFU} / \mathrm{g} \mathrm{DM}$. whereas aflatoxins by the ELISA method aflatoxin kits (AF) (RIDASCREEN FAST, R-Biopharm AG) were detected in 60 samples taken. This study indicates the need for a continuous assessment of the mycological state of the smoked fish production chain in order to guarantee consumer safety. SAS software was used for all analyzes and the differences were considered significant when $\mathrm{p}<0.05$.
\end{abstract}

Keywords: peach, smoked fish, aflatoxins, mycoflora
Volume 8 Issue 4 - 2020

\author{
Christiane Demble, ${ }^{1,3}$ Ousmane Diarra, ${ }^{1,2}$ \\ Amadou Hamadoun Babana, ${ }^{2}$ Fassé \\ Samake, 1,2 Boubacar Madio dit Aladiogo \\ Maiga, ${ }^{3}$ Kadia Maiga,' Mahamadou Diarra,' \\ Atia Traore,' Djeneba Ouattara,' Djeneba \\ Nantoume,' Ibrahima Malle' \\ 'Research Laboratory in Microbiology and Microbial \\ Biotechnology, Faculty of Sciences and Techniques, University of \\ Sciences, Techniques and Technologies of Bamako, Mali \\ ${ }^{2}$ Institute of Applied Sciences-ISA Badalabougou University \\ Campus, Mali \\ ${ }^{3}$ LCV-Central Veterinary Laboratory, Mali
}

\author{
Correspondence: Ousmane Diarra, Research Laboratory \\ in Microbiology and Microbial Biotechnology, Faculty of \\ Sciences and Techniques, University of Sciences, Techniques and \\ Technologies of Bamako, Bamako, Mali, BPE: 3206, \\ Tel 00223727978 02, Email diarraousmane758@gmail.com
}

Received: June 19,2020 | Published: July 13, 2020

\section{Introduction}

Fishing is a millennial tradition in Mali. It is an important subsector of the Malian economy, depending in particular on the Niger River, which is 4,200 km long, including $1,700 \mathrm{~km}$ in Mali. Its potential importance of existing resources is expressed in its sociocultural role, job creation, food security and poverty reduction. National fishery production, estimated at 100,000 tonnes of fish per year during normal hydrology, places Mali third among African countries producing freshwater fish. ${ }^{1}$ The gross value added of the fishing industry amounts to CFAF 90 billion, or more than $4 \%$ of national GDP on the basis of this 100,000 tonnes per year. Fishing also contributes substantially to the state budget, thanks to the fees paid by the actors in the sector and the taxes and levies levied throughout the sector. The whole of this contribution is estimated at around $10 \%$ of the gross value added of the sector. ${ }^{1}$ Fish is a natural food that humans have eaten since the dawn of time. Very early on, it was recognized as favorable to a good physiological balance. More recently, the protective effect against cardiovascular disease has been the subject of numerous studies and is now recognized. ${ }^{2}$ These facts have been linked to the particular chemical composition of fishery products: richness in proteins and essential amino acids (lysine, methionine, tryptophan, histidine) and in polyunsaturated fatty acids, prostanoid precursors having an anti thrombotic effect. ${ }^{2}$ However, we should not forget their richness in vitamins: fish has been the only source of vitamin D for a long time and remains a notable supplement in group B vitamins. It contains vitamin A stored in the form of retinol in the liver, intestines, pancreas, and kidneys. Food canning practices, as is the case in industrialized countries, is not an appropriate method of preserving products in sub-Saharan African countries because it requires high energy consumption and advanced technologies. ${ }^{3}$ Various studies have shown the presence of aflatoxins in several foodstuffs and their impacts on agriculture, the economy and public health. Of these different studies, we cite, that carried out by ${ }^{4}$ has shown the simultaneous presence of Aspergillus flavus and aflatoxin in peanut samples from the rural commune of Dafèla in the circle of Kita. ${ }^{4}$ Although peanuts are widely used in food and feed, smoked fish are no less because they are a very important source in human food.

\section{Material and methods}

\section{Material}

In this study, smoked fish (clarias anguillaris) were used as biological material.

\section{Sampling}

The microbiological analyzes covered 60 samples from the six communes of bamako due to ten (10) samples per commune and two (02) samples per market. The samples weighed between 200 and 300 $\mathrm{g}$ representing lots of fish once purchased, the samples were put in plastic bags and well labeled and sent directly to the laborrem-biotech of the f.s.t for analysis (Figure 1).

\section{Laboratory analysis}

\section{Fungal count}

One (01) gram of smoked fish was dispersed in $9 \mathrm{ml}$ of a $0.05 \%$ solution of TWEN 80 using a mixer (vortex). Decimal dilutions have been made up to 10-6. One (01) $\mathrm{ml}$ of each of the decimal dilutions was spread on PDA. Typical mushroom colonies were counted after 3,5 and 7 days of culture at $25^{\circ} \mathrm{C}$. The fungi were identified using the identification key according to. ${ }^{5}$ The Aspergillus were distributed in Petri dishes by successive subculturing both on Rose Bengal agar and PDA (Figure 2). 


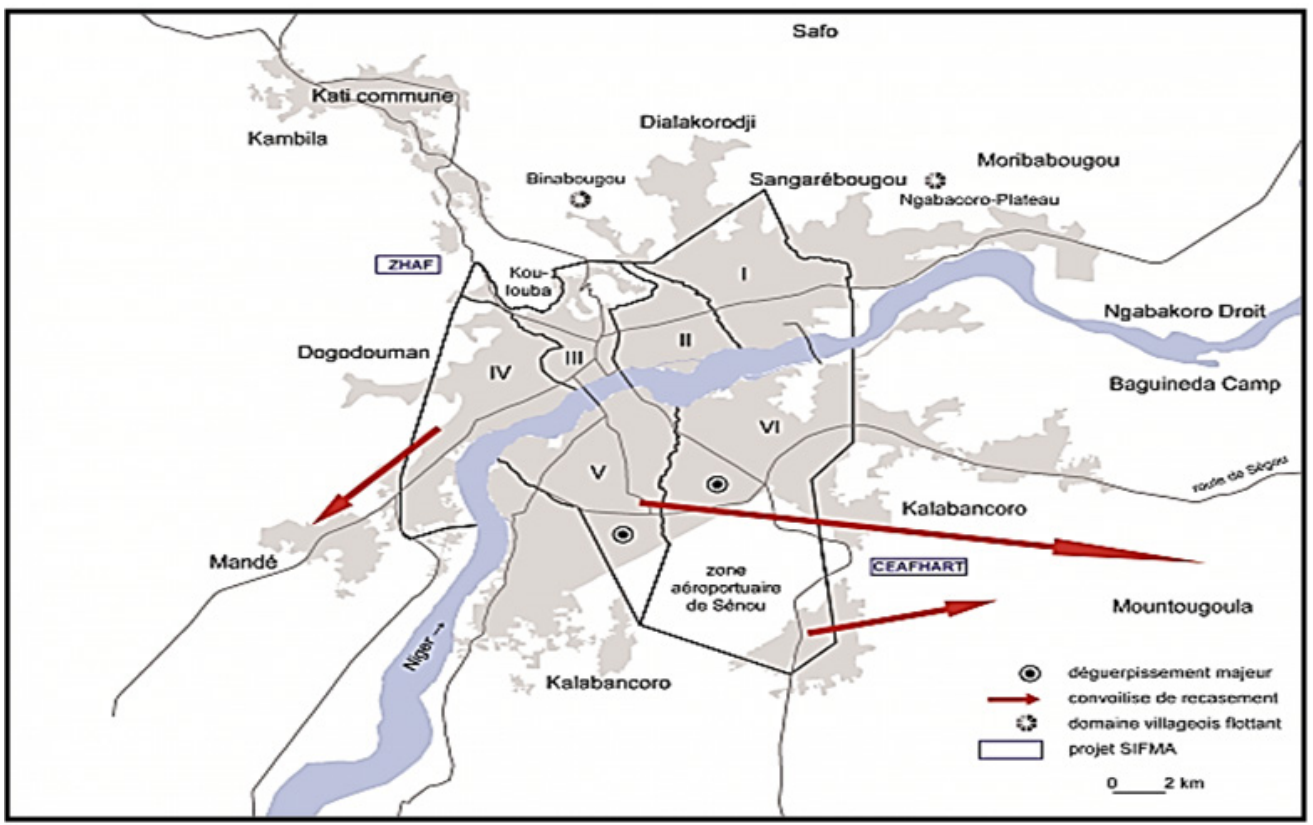

Figure I Map of Bamako (The district divided into 6 municipalities by ordinance ${ }^{\circ} 78-32 \mathrm{CMLN}$ of August 18, 1978 modified by a law in February 1982).

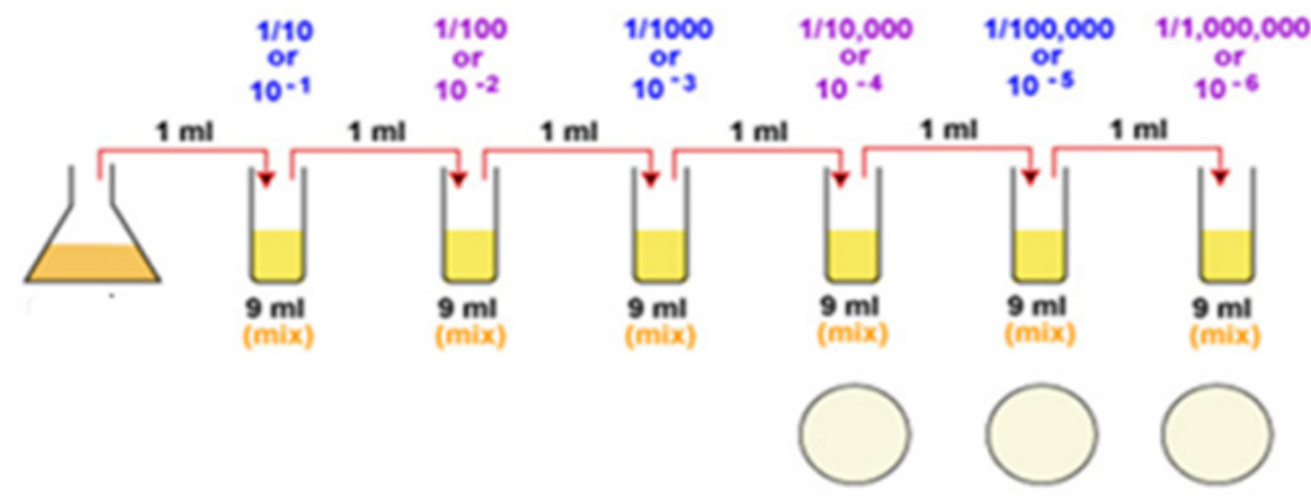

Figure 2 Dilution scheme.

\section{Expression of results}

$\mathrm{N}=\mathrm{V} \cdot \mathrm{d} \cdot \mathrm{C}$

$\mathrm{N}$ : Number of CFUs per gram of fish;

C: Sum of colonies of interpretable boxes;

$\mathrm{V}$ : Volume of solution deposited $(1 \mathrm{ml})$;

d: Dilution factor used.

\section{Isolation and purification}

The isolation of the strain was carried out from a consortium of fungi grown on a PDA medium. The selection of the strain was made by transplanting. For systematic identification, the purified isolate was subcultured on the Rose Bengal non-selective medium according to the methods used by. ${ }^{6}$

\section{Identification of the isolated strain}

The identification of the strain was carried out on pure cultures by observation of the macroscopic characters on the different culture media (growth, color, appearance of the colony) and microscopic characters using blue as a mounting solution under an optical microscope ( mycelium, conidiophores, conidia, resistance structures, possibly sexual form), with reference to different determination keys. ${ }^{7}$

\section{Mycotoxin production test}

The isolate was cultured on the production medium of aflatoxins AFPA medium (Aspergillus flavus and Aspergillus parasiticus), incubated at $25^{\circ} \mathrm{C}$ for 7 days, the fluorescence emitted under UV is detected. ${ }^{8}$ These are the Aspergillus flavus, Aspergillus parasiticus and Aspergillus niger (Witness) strains. Aflatoxin toxins (AF) are highlighted through the back of the boxes.

\section{Extraction and determination of aflatoxins in fish}

To assess the presence of mycotoxins, fish samples were taken and subjected to quantitative analysis using ELISA aflatoxin kits (AF) (RIDASCREEN FAST, R-Biopharm AG). Briefly, $5 \mathrm{~g}$ of ground sample was put in $10 \mathrm{ml}$ of $70 \%$ methanol to extract the aflatoxins. Afterwards, the samples were shaken vigorously for 3 minutes and the extracts were precipitated by the extraction solvent. Then, the aflatoxins, were diluted with distilled water in the ratio 1: 1 . One hundred $\mu \mathrm{L}$ of the filtrate diluted by cassette of Rida quick scan was used for the tests (Figure 3). ${ }^{9}$ 


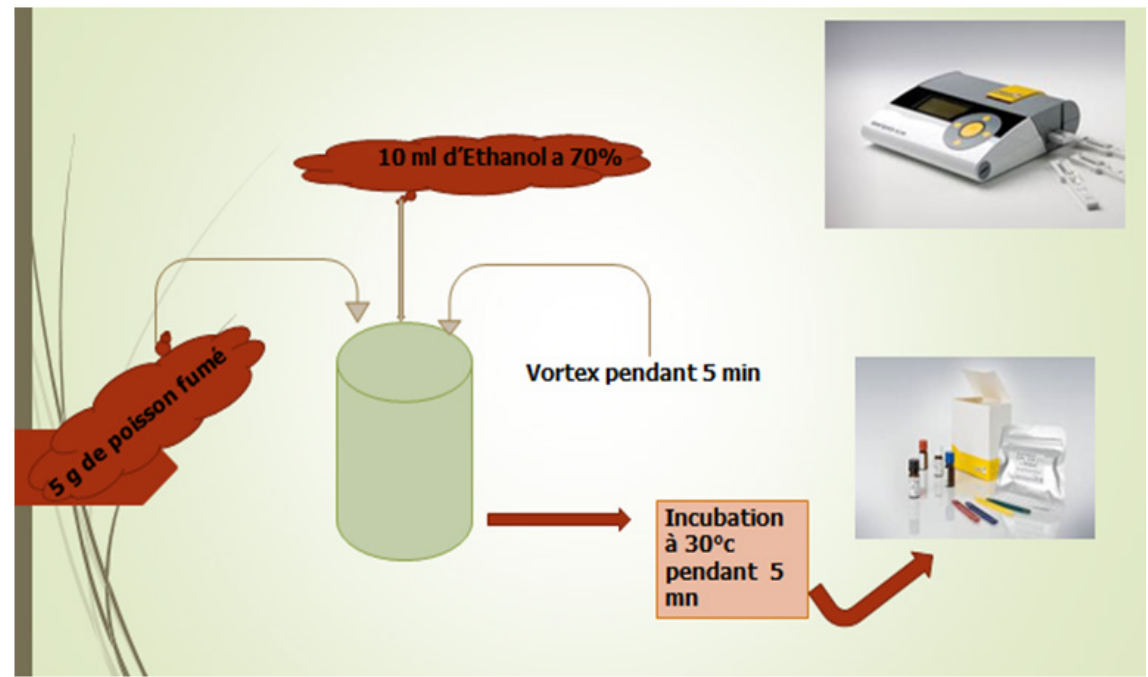

Figure 3 Determination of mycotoxins in smoked fish.

\section{Data analysis}

The variance analysis test was used to analyze the fungal count and the toxin content. Before the analysis, the homogeneity of the variance of the data was checked. The non-homogeneous data have been transformed. Multiple range tests were used to compare the means of fungal counts and toxin content of samples from different communes. SAS software version 9.4 was used for all analyzes and the differences were considered significant when $\mathrm{p}<0.05$.

\section{Results and discussion}

\section{Enumeration}

Table 1-3.

Table I Fungal load of smoked fish samples from different municipalities after 7 days of incubation

\begin{tabular}{lll}
\hline Municipalities & Neighborhoods & Fungal flora $1 \mathbf{0}^{4} \mathbf{U F C} / \mathbf{g}$ \\
\hline & Boulkassombougou & 2,75 \\
& Djélibougou & 10,5 \\
& Fadjiguila & 0,5 \\
& Doumanzana & 10,25 \\
& Banconi & 9,25 \\
II & Missira & 5,75 \\
& Quinzambougou & 3,25 \\
& N'golonina & 10,5 \\
& Medina coura & 7,5 \\
& Bagadadji & 10,75 \\
Dibida & 11,75 \\
& Bolibana & 6,25 \\
& Ouolofobougou & 1,75 \\
& Badialan & 0,5 \\
Darsalam & 2 \\
& &
\end{tabular}

\begin{tabular}{lll}
\hline Municipalities & Neighborhoods & Fungal flora $10^{4} \mathbf{U F C} / \mathbf{g}$ \\
\hline & Lafiabougou & 12,25 \\
& Talko & 7,75 \\
& Sebenicoro & 6,5 \\
& Hamdallaye & 1 \\
& N'tomicorobougou & 0,5 \\
V & Kalaban coura & 5,25 \\
& Sabalibougou & 5,5 \\
& Daoudabougou & 3,25 \\
& Torokorobougou & 2,25 \\
& Djicoroni & 2 \\
& Niaamakoro & 3 \\
& Magnambougou & 2 \\
& Banankabougou & 3,75 \\
& Yirimadjo & 4,75 \\
& Sogoniko & 2,5 \\
\hline
\end{tabular}

Table 2 Variance analyzes of the fungal flora of smoked fish according to the different municipalities and districts, as well as the mushroom concentration

\begin{tabular}{llll}
\hline & & \multicolumn{2}{l}{ Fungal flora } \\
\cline { 3 - 4 } Source & DDL & Medium square & Value of $\mathbf{F}$ \\
\hline Municipalities & 5 & $0,010^{* *}$ & 0.79 \\
Neighborhoods & 29 & $0,15^{*}$ & 11.5 \\
Iteration & 3 & $0,075^{* *}$ & 5.83 \\
\hline
\end{tabular}

*, **, significant at $\mathrm{P}<0.05$ and $\mathrm{P}<0.0 \mathrm{I}$, respectively

Mushroom content varies from fish to fish 
Table 3 Comparison of the averages of the fungal flora of smoked fish according to the municipalities

\begin{tabular}{llll}
\hline Fungal flora & & & \\
\hline Municipalities & Nb & Average & Standard deviation \\
\hline $\mathrm{Cl}$ & 10 & $6.77^{\mathrm{a}}$ & $4.3 \mathrm{I}$ \\
$\mathrm{CII}$ & 10 & $5.88^{\mathrm{b}}$ & $4.1 \mathrm{I}$ \\
$\mathrm{CIII}$ & 10 & $5.02^{\mathrm{b}}$ & 5.5 \\
$\mathrm{CIV}$ & 10 & $4.82^{\mathrm{c}}$ & 4.45 \\
$\mathrm{CV}$ & 10 & $3.52^{\mathrm{d}}$ & $1.3 \mathrm{I}$ \\
$\mathrm{CVI}$ & 10 & $3.22^{\mathrm{d}}$ & 1.83 \\
\hline
\end{tabular}

For each mean value of fungal flora in each column, the means followed by the same letter are not statistically different according to the Lsd test protected by Fisher $(P<0.05)$

In view of the results obtained in table 1 above, we can note that the fungal count of all the samples of smoked fish taken in the different municipalities: I, II, III, and IV was higher than the norm from the $5^{\text {th }}$ day, while in commune $\mathrm{V}$, the threshold is exceeded from the $7^{\text {th }}$ day. According to ${ }^{10}$ the mycological quality of food can be qualified as good with a number of fungus $<3.10^{4} \mathrm{CFU} / \mathrm{g}$ and bad for those with a number $>7.10^{4} \mathrm{CFU} / \mathrm{g}$ ). On the other hand in commune VI, in certain districts (Niamakoro; Banankabougou) the threshold is exceeded from the 3rd day. Lack of good hygiene practices and poor storage of smoked fish can cause fungal contamination. Contamination by fungi can also be due to the spraying of fish with water to increase the weight during the sale because humidity is a factor favoring the proliferation of fungi (Figure 4).

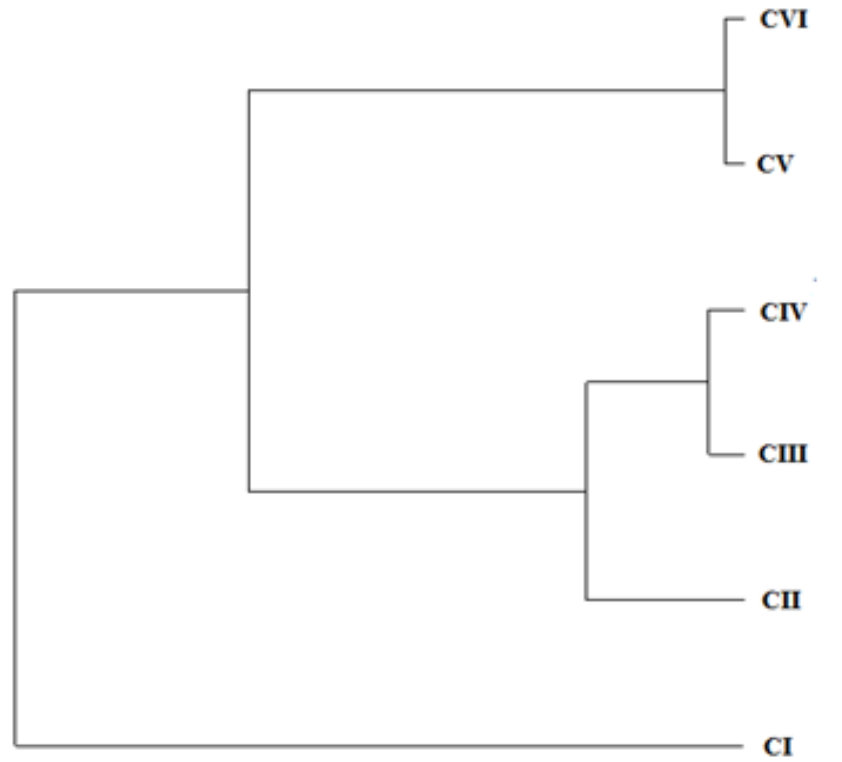

Figure 4 Dendrogram of the different municipalities.

\section{Isolement et purification}

Figure 5 .

\section{Mycotoxin production test}

The production of aflatoxins is highlighted through the underside of the boxes by changing the color to dark yellow (Figure 6).

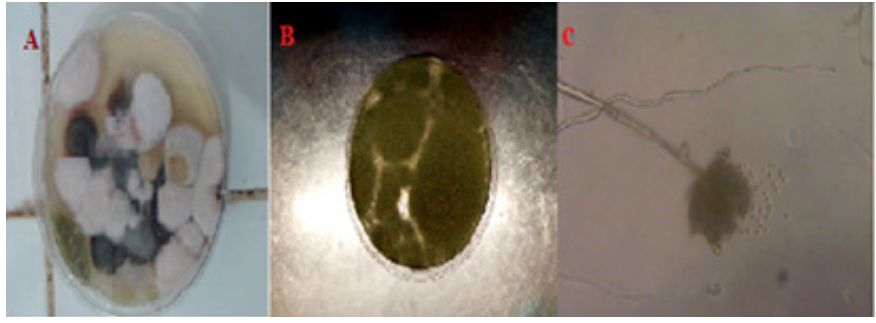

Figure 5 Isolation purification and identification of Aspergillus flavus.

A: Mushroom consortium on PDA

B: Purified Aspergillus flavus

C: Microscopic appearance of Aspergillus flavus with cotton blue.

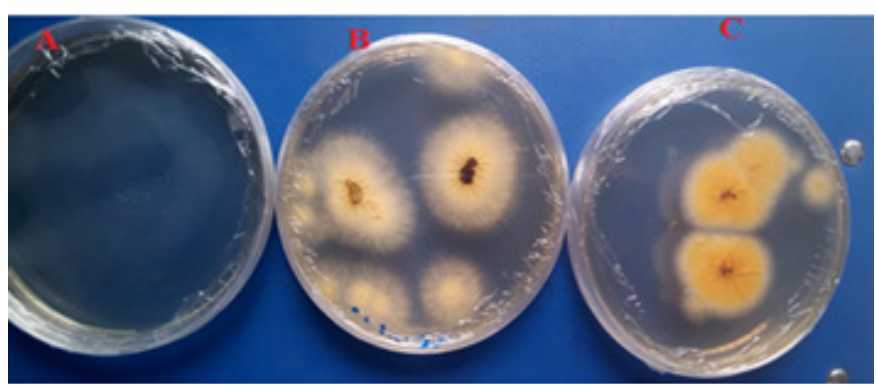

Figure 6 Aflatoxin production on AFPA medium.

A: Negative control (AFPA environment); B: Negative control (Aspergillus niger); C: Aspergillus flavus.

\section{Aflatoxins extraction and dosage in fish}

Table 4.

Table 4 Determination of aflatoxins in smoked fish samples

\begin{tabular}{|c|c|c|c|}
\hline Municipalities & Neighborhoods & Presence & $\begin{array}{l}\text { Quantity of } \\
\text { Aflatoxins }\end{array}$ \\
\hline \multirow{5}{*}{ I } & Boulkassombougou & + & $<4 \mathrm{ppb}$ \\
\hline & Djélibougou & + & $<4 \mathrm{ppb}$ \\
\hline & Fadjiguila & + & $<4 \mathrm{ppb}$ \\
\hline & Doumanzana & + & $<4 \mathrm{ppb}$ \\
\hline & Banconi & + & $<4 \mathrm{ppb}$ \\
\hline \multirow{5}{*}{ II } & Missira & + & $<4 \mathrm{ppb}$ \\
\hline & Quinzambougou & + & $<4 \mathrm{ppb}$ \\
\hline & N'golonina & + & $<4 \mathrm{ppb}$ \\
\hline & Medina coura & + & $<4 \mathrm{ppb}$ \\
\hline & Bagadadji & + & $<4 \mathrm{ppb}$ \\
\hline \multirow{5}{*}{ III } & Dibida & + & $<4 \mathrm{ppb}$ \\
\hline & Bolibana & + & $<4 \mathrm{ppb}$ \\
\hline & Ouolofobougou & + & $<4 \mathrm{ppb}$ \\
\hline & Badialan & + & $<4 \mathrm{ppb}$ \\
\hline & Darsalam & + & $<4 \mathrm{ppb}$ \\
\hline
\end{tabular}


Table Continued...

\begin{tabular}{|c|c|c|c|}
\hline Municipalities & Neighborhoods & Presence & $\begin{array}{l}\text { Quantity of } \\
\text { Aflatoxins }\end{array}$ \\
\hline \multirow{5}{*}{ IV } & Lafiabougou & + & $<4 \mathrm{ppb}$ \\
\hline & Talko & + & $<4 \mathrm{ppb}$ \\
\hline & Sebenicoro & + & $<4 \mathrm{ppb}$ \\
\hline & Hamdallaye & + & $<4 \mathrm{ppb}$ \\
\hline & N'tomicorobougou & + & $<4 \mathrm{ppb}$ \\
\hline \multirow{5}{*}{ V } & Kalaban coura & + & $<4 \mathrm{ppb}$ \\
\hline & Sabalibougou & + & $<4 \mathrm{ppb}$ \\
\hline & Daoudabougou & + & $<4 \mathrm{ppb}$ \\
\hline & Torokorobougou & + & $<4 \mathrm{ppb}$ \\
\hline & Djicoroni & + & $<4 \mathrm{ppb}$ \\
\hline \multirow{5}{*}{ VI } & Niaamakoro & + & $<4 \mathrm{ppb}$ \\
\hline & Magnambougou & + & $<4 \mathrm{ppb}$ \\
\hline & Banankabougou & + & $<4 \mathrm{ppb}$ \\
\hline & Yirimadjo & + & $<4 \mathrm{ppb}$ \\
\hline & Sogoniko & + & $<4 \mathrm{ppb}$ \\
\hline
\end{tabular}

In all the municipalities and all the districts, the samples were positive however they were all below the European Union standard $(<4 \mu \mathrm{g} / \mathrm{Kg}$ or 4 ppb according to'")

\section{Dicussion}

According to the mycological quality criterion, ${ }^{10}$ the mycological quality of food can be described as good with a number of fungus $<3.10^{4} \mathrm{CFU} / \mathrm{g}$ and bad for those with a number $>7.10^{4} \mathrm{CFU} / \mathrm{g}$ ). The fungal load of all the smoked fish samples taken in communes I, II, III, and IV was higher than the norm, while in commune V, VI the fungal load was clearly lower than the norm. Our results differ from those obtained by ${ }^{12}$ who showed that the samples of livestock feed sold in Bamako were heavily contaminated with toxicogenic fungi. Xerophilic fungi, capable of growing rapidly above about 0.77 as a water activity (Aw), can cause spoilage of animal feed. ${ }^{13}$ Evaluation of the total fungal flora of smoked fish has shown that it contains approximately 0.5.10 $\mathrm{CFU} / \mathrm{g}$ to $14.10^{4} \mathrm{CFU} / \mathrm{g} \mathrm{DM}$. This value was calculated only from samples grown in PDA medium at $30^{\circ} \mathrm{C}$ since almost all isolated fungal species can germinate and grow at this temperature, although it is not optimal for thermophilic species. Our results are slightly lower than those obtained by ${ }^{14}$ who obtained $0.810^{5}$ to $14.89 .10^{5} \mathrm{CFU} / \mathrm{g}$ DM. Lack of good hygiene practices and poor storage of smoked fish can cause fungal contamination. Contamination by fungi can also be due to the spraying of fish with water to increase the weight during the sale because humidity is a factor favoring the proliferation of fungi. The production conditions for the smoked Clarias anguilaris fish and the sale in the district markets reveal a total lack of hygiene and conservation. The high contamination of fish can be explained by the great capacity of yeasts and molds to develop on substrates with low water activity. ${ }^{15}$ Our results are comparable to those of ${ }^{12}$ who obtained $10 \%$ of his samples contaminated by yeasts and molds.

\section{Conclusion}

This study consisted in characterizing the fungal flora and the degree of aflatoxin contamination in smoked fish sold in the various municipalities of the district of Bamako. Mycological analysis of the smoked Clarias anguillaris sold in the six (06) communes of the Bamako District shows that much remains to be done to guarantee the health of consumers. The samples contained an average fungal load of 7,25.104 $\mathrm{UFC} / \mathrm{g}$ of fish higher than the norm and the presence of Aspergillus flavus capable of producing aflatoxins in food as well as on the AFPA medium was demonstrated. Aflatoxin was found in all samples at levels below 4ppb. This Master thesis is a contribution to the current debate on the risks linked to fungal contamination of smoked fish. The high concentrations of fungi and the presence of mycotoxins (Aflatoxins) show that there are quality problems with smoked fish.

\section{Acknowledgments}

Christiane DEMBELE is a student in Master microbiology option food control and quality at the Research Laboratory in Microbiology and Microbial Biotechnology (REM-Biotech Lab), Faculty of Sciences and Techniques - University of Sciences, Techniques and Technologies of Bamako. His studies and research work are supported by a grant from the Central Veterinary Laboratory of Mali (LCV). We thank the Central Veterinary Laboratory of Mali for their financial and management support.

\section{Conflicts of interest}

Authors declare that they have no conflict of interest.

\section{References}

1. Bayogo B. Characterization of fisheries and fish species in the municipality of Markala and Pelengana (Ségou) and climate change II); 2004. 25 p.

2. Ouattara. Contribution to the study of the quality of processed fish (smoked, dried) in Bamako, Mopti, Niono. Doctoral thesis in pharmacy: FMPOS Bamako; 2005. 15 p.

3. Heilporn L. Development of a rational method of drying fish using solar energy in Mali; 2011.

4. Tekete C. Detection of the simultaneous presence of aflatoxins and Aspergillus strains by the ELISA test and the PCR on peanuts in Mali DEA thesis; 2009

5. Botton B, Breton A, Fèvre $\mathrm{M}$, et al. Useful and harmful molds. Industrial significance, Dunod: Paris; 1990.

6. Pitt J, Hocking AD. Fungi and Food Spoilage. Blackie Academic and Professional: London; 2015.

7. Pacin AM, Gonzalez HHL, Etcheverry M, et al. Fungi associated with food and feed commodities from Ecuador. Mycopathologia. 2003;156(2):8792.

8. Greco MV, Pardo AG, Ludemann V, et al. Mycoflora and natural incidence of selected mycotoxins in rabbit and chinchilla feeds. Sci World J. 2012;2012:956056.

9. Thom C, Church MB. The Aspergilli. London: Baillière, Tindall \& Cox; 1926. 271 p.

10. Gimeno A. Fungi and Mycotoxins in Animal Feed; Concepts, Problems, Control and Recommendations; 2002.

11. Sarma UP, Bhetaria PJ, Devi P, et al. Environmental occurrence of Aspergillus and other fungal spores are hazardous to humans and animals. Indian Journal of Clinical Biochemistry. 2017;32:124-133.

12. Diarra O, Babana AH, Maïga K. Fungal profile and mycotoxin contamination in animal feed in urban and peri-urban zones of Bamako. Int J Curr Res Biosci Plant Biol. 2017;4(11):50-56. 
13. Pitt JI. Toxigenic fungi and mycotoxins. Br Med Bull. 2009;56(1):184192.

14. Btissam M, Amina OT, Allal D. Isolation and identification of mycoflora from solid urban waste compost. Nature \& Technology. 2013;9:13-28.
15. Annabi M, Le Bissonnais Y, Francou C, et al. Use of composts to improve the structural stability of loamy soils; 2005. 